\title{
Role of Spirituality in Sustainable Development
}

\author{
Neha Mahesh Inamdar
}

\begin{abstract}
Looking beyond the materialistic boundary of the conventional development paradigm, it is very important to keep a balance between the external changes and the changes which needs to be done within. Unfortunately Conventional development's overemphasis on external changes, and it ignores inner changes, it may be because of the reflection of the prevailing general belief. Now a day the sense of ' $I$ ', self-centeredness and greed which is actually an inherent human characteristics common to all human beings is seen to be taking the charge of the personality and becoming dominant. As we all are talking about the Globalization, Artificial Intelligence, Machine Learning, Robotics all this put together will definitely create a competition where the human beings will have to prove themselves better than the machines, this may lead to various problems such as stress, anxiety, depression, performance anxiety so forth and so on. The fundamental differences between the machines and human beings can be explained as; human beings are having (1) Empathy - the capacity to sense others' feelings, (2) Loving kindness - the wish of others' happiness, (3) Compassion - the wish to alleviate others' suffering and (4) Generosity - the willingness to share one's wealth with others in order to reduce their suffering. In other words we can say that the human beings are having thought ware. There is a need to understand that merely achieving money or position cannot be the sole measure to decide the success or failure of a person.

Currently various initiatives are taken on design thinking, positive thinking and meditation. Even the school children are also having meditation as a part of their daily routine. It is seen that many of the youngsters are becoming victim of depression and fail to maintain their mental balance. The researcher strongly feels that for having a sustainable development people need to be spiritually ignited. In this paper the researcher has tried to relate the sustainable development with spirituality. For material development to be sustainable, spiritual advancement must be seen as an integral part of the human development algorithm.
\end{abstract}

Keywords : Spirituality, empathy, compassion, thoughware.

\section{INTRODUCTION}

In $21^{\text {st }}$ Century we have seen various advancements related to science, technology and almost all the sectors. Still we can find that people are always in a stress and are always busy either in maintain their status, earning money, completing their targets so forth and so on. Even in today's society going for a vacation is also seen as a status symbol. In this regard it is very essential for an individual to understand what and why is this life. In this paper the researcher tried to relate and alien the thought process of an individual in a spiritual direction so as to control the unnecessary thoughts and concentrate more. For sustainable development it is very

Revised Manuscript Received on February 06, 2020.

* Correspondence Author

Mrs. Neha Inamdar*, Industry Institute Interaction Department, University of Pune, Nigadi, India. Email: nehamaheshan1003@gmail.com much essential for an individual to maintain their mental health if we classify 3 important part of our life then mental health, physical health and financial health are very important. Every one needs to keep a balance between these 3 to have a sustainable development. Any mess in any of these will cause a imbalance and disturbance in life. The researcher believes that everyone cannot achieve everything so if the individual can make a paradime shift in the thought process then the things will become easy.

Today as stated earlier the sense of "I" is taking charge of everything, people started believing that whatever is happening is because of the struggle done by them and they can control everything in their life. Here unfortunately we are forgetting that human beings or individuals are nothing, but! Have to do everything. Honestly speaking despite of all the advancements done in medical science human beings don't have control on the birth, death or gender of the fetus. So we must believe that there is something which is bigger than human beings and surrender ourselves to that Devine Power. With the help of this paper the researcher is going to see how the spirituality helps in maintaining the sustainable development.

Spirituality is a broad concept having room for many perspectives. In general, it includes a sense of connection to something bigger than ourselves, and it typically involves a search for meaning and happiness in life. On the other hand sustainable development refers to meeting the needs of the present without compromising the ability of future generations to meet their own needs. Again when we talk about the sustainable development we must understand that whatever we have today must remain constant and we must add value to it every day. Sustainability refers to the perpetual succession related to mind and body.
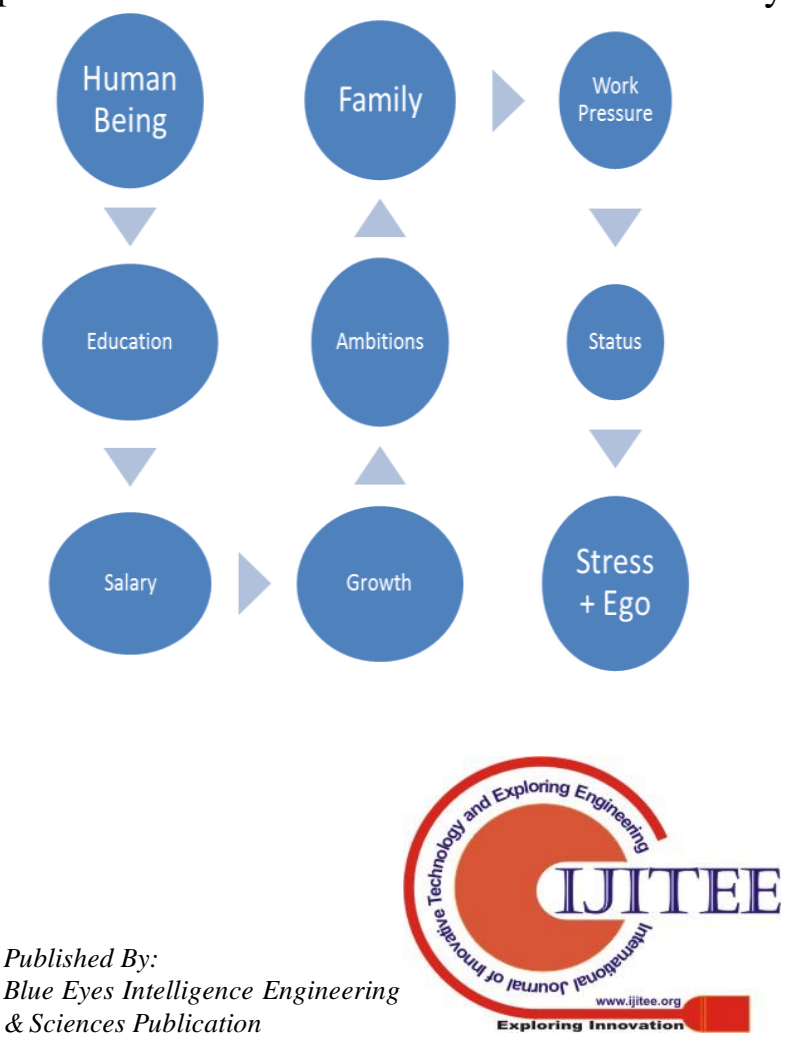


\section{Role of Spirituality in Sustainable Development}

\section{PROCEDURE FOR PAPER SUBMISSION}

During this study more emphasis is given on the thoughts and thought process of the respondents.

In this regards the researcher has studies 40 individuals who are working in different organizations from the age group of 35 to 40years both male and female. The samples were selected randomly.

Based on the questionnaire and personal interview the research work was carried out. The questions related to stress, view point about life, what success means to you ..so forth and so on were asked and some inferences are drawn which will definitely add value. After the questionnaire one exercise was given to the participants and it was monitored as well. The researcher has also studied the before and after effects.

During the discussion it was found that many of the respondents are doing everything but still are some or the other way unhappy with whatever they are doing and then as a result a lot of stress, anxiety and negativity was observed. Based on the overall discussion a common thread was found between the $43 \%$ respondents and they were divided into 3 broader groups.

As the problems or concerns faced by them are more or less similar the spiritual counseling given to them was also same. During the initial stages the respondents found it difficult to concentrate and even not ready to take the exercise but later on after 2 to 3 sessions they started feeling the difference and then they proactively took the exercise and try to practice it.

Table 1

\begin{tabular}{|c|c|c|c|c|c|c|}
\hline $\begin{array}{c}\text { Sr. } \\
\text { No. }\end{array}$ & Questions & $\begin{array}{c}\text { Strongl } \\
\text { y Agree }\end{array}$ & $\begin{array}{c}\text { Agre } \\
\mathrm{e}\end{array}$ & $\begin{array}{c}\text { Almos } \\
\mathrm{t} \\
\text { Agree }\end{array}$ & $\begin{array}{c}\text { Disa } \\
\text { gree }\end{array}$ & $\begin{array}{c}\text { Strongl } \\
\text { Disagre } \\
\mathrm{e}\end{array}$ \\
\hline 1 & $\begin{array}{c}\text { I feel Stressed } \\
\text { most of the time. }\end{array}$ & 5 & 6 & 7 & 12 & 10 \\
\hline 2 & $\begin{array}{c}\text { I can control my } \\
\text { anger }\end{array}$ & 8 & 12 & 9 & 9 & 12 \\
\hline 3 & $\begin{array}{c}\text { I always complete } \\
\text { my planned work } \\
\text { in time. }\end{array}$ & 9 & 8 & 2 & 15 & 6 \\
\hline 5 & $\begin{array}{c}\text { I feel I have got } \\
\text { almost everything } \\
\text { I want. }\end{array}$ & 5 & 9 & 5 & 18 & 3 \\
\hline 7 & $\begin{array}{c}\text { I feel there is } \\
\text { peace, joy and } \\
\text { satisfaction within } \\
\text { me and not in the } \\
\text { world around me. }\end{array}$ & 4 & 9 & 5 & 15 & 7 \\
\hline $\begin{array}{c}\text { I have a sense of } \\
\text { gratitude and } \\
\text { tanks giving in } \\
\text { life. }\end{array}$ & 10 & 2 & 5 & 17 & 5 \\
\hline $\begin{array}{c}\text { I believe that } \\
\text { everything in life } \\
\text { is not in the } \\
\text { control of human. }\end{array}$ & 7 & 5 & 5 & 16 & 6 \\
\hline
\end{tabular}

From the above table we can see that majority of the respondents are feeling that they are stressed and sometimes feel helpless during their daily life. They also have a belief that everything in their life is in their control. When these respondents were interviewed they were very candid and open in the due discussion it is found that happiness or a sense of completeness is majorly depending upon the external factors and once we have that particular thing then later on the utility in that thing ends and again something else become our dream and the race begins. It was also observed that something lets say for an example a having premium car is a dream of person $\mathrm{x}$, but person $\mathrm{Y}$ who has a premium car is dreaming to have a private Jet so this vicious circle is never ending.

The respondents also share about the difficult time they faced and who they came out from that particular situation, $57 \%$ of the respondents say that the difficult time made them realize that there is something which is far bigger than the human and they surrendered themselves to that Divine Power. These $57 \%$ people also have a habit of prayer, mediation or just a self talk as a part of their daily routine.

On the other hand the $43 \%$ of the respondents said that they are the one who faced the difficulties in every aspect of their life and actually nothing works as they wanted but because of the struggle and efforts made by those individuals they came out of those difficulties and settled in their life. Few questions related to happiness were asked where the answers were somewhat similar and were more focused on the materialistic life. A simple question was asked that what is the greatest gift you want to give to your kid? The answers were full of luxurious life, expensive accessories, foreign education, expensive gifts and many more but one answer which was very interesting is "A simple warm hug to my child will be the greatest gift".. really a great answer it was.

One more question was asked to the respondents about "if given an opportunity what would you have changed in your past life?" 10 respondents answered they would have changed their parents, 5 said they would have changed their spouse few said their / their parents financial status, few said they would have changed the country so forth and so on. respondents were of the opinion that why only one, I want to change all my past and rebuild it.

Based in the overall observation it was found that $53 \%$ of the respondents are having positive mindset towards their life and $47 \%$ are not so happy for their life and are almost stressed at all the times. These $47 \%$ respondents were divided in 3 groups and with similar problem statement.

For Group 1 - it was decided that they will make the effort to complete the planned work for the day on the same day.

\section{Group 1 - Make eftort to complete the work planned of the day}

\section{$17 \%$}

Feel the

positive

Difference

No change

$83 \%$

These group members were very much annoyed because they were not able to complete their work in time irrespective of the quantity and quality of work. For 15 days these members were given a 
spiritual counseling and after that a effort was made to understand whether they are able to make it or not.

During the discussion it was found that $83 \%$ of the members feel that now they can plan and finish the decided work in time still there are $17 \%$ members who are still not able to see any positive change in their routine.

For Group 2 - it was decided that they will make efforts to reduce the stress level.

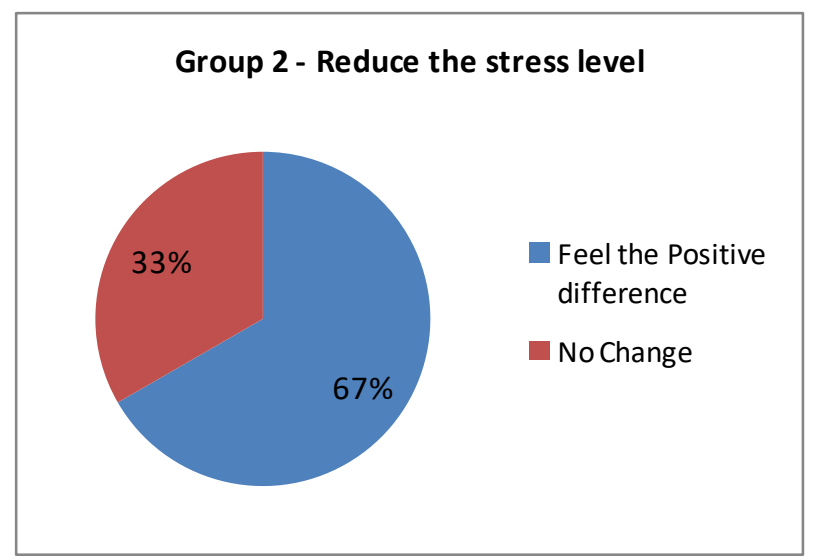

These group members were having a high level of stress. For 15 days through a what's app session spiritual counseling given to them for 15 minutes a day and asked them to practice certain techniques whenever they feel stressed. After 15 days the respondents shared that stress level was redunced to a remarkable level still around $33 \%$ of the respondents couldn`t see much change.

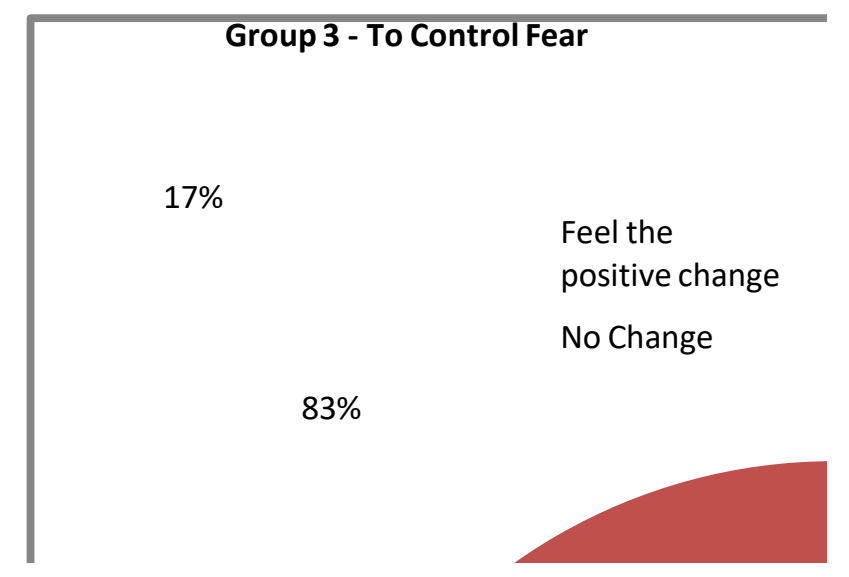

For Group 3 - the task was undertaken to control the fear.

These respondents shared that they feel that whatever is happening or will happen will have a negative impact on their life. So they resist themselves from any change. This group was also given a spiritual counseling for 15 days and the results were amazing, $83 \%$ respondents felt that now they can face the future with more confidence. After 15 days a consolidated feedback was taken which showed that the respondents were very motivated and even the peer members observed and acknowledged the changed behavior of the respondents.

\section{CONCLUSION}

To conclude researcher wants to say that for a sustainable development the role of thoughts and thought process is important and in this society human being must understand the importance of mental and physical health rather than only satisfying and improving the financial health.

After the spiritual counseling given to the respondents there was a visible positive change in their behaviors the researcher also spoke with the peers of the respondents to know the results the response was positive.

It is also suggested based on the study that for having a healthy life everyone must be spiritually enlightened and to start with must meditate for 15 minutes a day.

\section{REFERENCES}

1. Paper published by Mr. Sandeep Kumar on Spirituality And Sustainable Development: A Paradigm Shift http://iesd.org.in/jesd/Journal\%20pdf/2017-XIII-1\%20Spirituality\%20a nd\%20Sustainable\%20Development.pdf

2. BOOK - SPIRITUALITY AND SUSTAINABLE DEVELOPMENT BY ROHANA ULLUWISHEWA.

3. article - the rising culture and worldview of contemporary spirituality: a sociological study of potentials and pitfalls for sustainable development. HTTPS://WWW.SCIENCEDIRECT.COM/SCIENCE/ARTICLE/PII/S092180091 $\underline{1000486}$

4. Master Degree Project by Nidhi Jain on Connection between Spirituality and Sustainable Development https://prism.ucalgary.ca/bitstream/handle/1880/41193/2001_Jain?sequ $\underline{\text { ence }=1}$

\section{AUTHORS PROFILE}

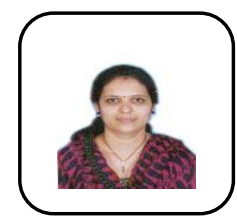

MPM, Pursuing M.Phil. from SPPU 10years experience in Training and Placements

Head Corporate Relations - MBA@IICMRTaking care of end to end campus placements and Corporate Interface of MBA@IICMR. Making the students job ready and place them in respective companies according to their specialization is taken care by the Corporate Relations team. Here my core expertise are to guide the student to decide their career goals understand their potential and areas of concern which may become barrier during the campus placement process and their final placement.

In addition to this understanding the requirement from the company and getting exactneed and accordingly line up the students is also a skill. Published 3 papers in National Journals on employability. 